\title{
Mechanical Properties of Zirconia-Alumina Whisker Composite Ceramics
}

\author{
Nobuyuki TAMARI, Takahiro TANAKA, Isao KONDOH, Saburoh KOSE and Kohji GOTOH* \\ Government Industrial Research Institute, Osaka, 1-8-31, Midorigaoka, Ikeda-shi, Osaka 563 \\ *Technical Center for Machinery and Metals, Hyogo Prefectural Institute of Industrial Research, \\ Aza Fuke, Hirata, Miki-shi, Hyogo $\quad$ 673-04 \\ ジルコニアーアルミナウイスカー系複合セラミックスの機械的性質 \\ 玉利信幸・田中隆裕・近藤 功・小瀬三郎・後藤浩二* \\ 大阪工業技術試験所, 563 池田市緑丘 1-8-31 \\ *兵庫県立工業技術センター機械金属指導所，673-04 三木市平田字フケ
}

[Received October 24, 1991; Accepted December 19, 1991]

\begin{abstract}
Zirconia ( $3 \mathrm{~mol} \% \mathrm{Y}_{2} \mathrm{O}_{3}$ ) composite ceramics reinforced with 10,20 and 40 vol $\% \alpha$-alumina whiskers were prepared by hot-pressing at $1500^{\circ} \mathrm{C}$ under $30 \mathrm{MPa}$ for 30 min, and the mechanical properties were measured. The $\alpha$-alumina whiskers were fabricated by thermal decomposition of aluminum borate $\left(9 \mathrm{Al}_{2} \mathrm{O}_{3} \cdot 2 \mathrm{~B}_{2} \mathrm{O}_{3}\right)$ whiskers at $1500^{\circ} \mathrm{C}$ for $72 \mathrm{~h}$ in air. Almost full dense composites $(>99 \%)$ were obtained by $1500^{\circ} \mathrm{C}$ hot-pressing. Improvement of room temperature bending strength was observed because of the whiskers. In fracture tests at $1200^{\circ} \mathrm{C}$, monolithic zirconia showed plastic deformation and bent, while the composite had a strength of around $300 \mathrm{MPa}$. Elastic modulus and hardness increased linearly with increasing whisker content. As the whisker content increased, fracture toughness also increased due to crack deflection by whiskers and pull-out of whiskers, and showed a maximum value (around $5.4 \mathrm{MPa} \cdot \mathrm{m}^{1 / 2}$ ) at the whisker content of 40 vol\%, which was 1.4 times as large as that of monolithic zirconia.
\end{abstract}

Key-words : Zirconia, Alumina whiskers, Composite ceramics, Hot-pressing, Mechanical properties

\section{Introduction}

Ceramic materials have been attracting much attention as structural materials, because of their high resistance to heat and chemicals and high strength at high temperature. However, they have the Achilles' tendon that they are brittle. One of the approach to improve its brittleness has been expecting to be reinforcement with whiskers. ${ }^{1,2)}$ Claussen et al. and Kondoh et al. have reported that an improvement in fracture toughness was observed by an incorporation of silicon carbide $(\mathrm{SiC})$ whiskers into zirconia containing $3 \mathrm{~mol} \% \mathrm{Y}_{2} \mathrm{O}_{3}$ (written $\mathrm{Z}-3 \mathrm{Y}$ for short in the following), but the room temperature bending strength decreased with increasing whisker content because of the high tensile matrix stresses due to the thermal mismatch $\left(\alpha_{\mathrm{Z}-3 \mathrm{Y}}=10 \times 10^{-6} / \mathrm{K}, \alpha_{\mathrm{SiC}}=4.7 \times 10^{-6} /\right.$ $\mathrm{K})$. $^{3), 4)}$ In this study, $\alpha$-alumina $\left(\mathrm{Al}_{2} \mathrm{O}_{3}\right)$ whiskers, whose thermal expansion coefficient $\left(\alpha=8.1 \times 10^{-6}\right)$ $\mathrm{K}$ ) was close to that of Z-3Y compared to $\mathrm{SiC}$, were used as the reinforcing material and the mechanical properties of $\mathrm{Z}-3 \mathrm{Y} / \mathrm{Al}_{2} \mathrm{O}_{3}$ whisker composite ceramics were investigated.

\section{Experimental}

The starting zirconia powder (Tosoh Co., TZ-3Y) contained $3 \mathrm{~mol} \% \mathrm{Y}_{2} \mathrm{O}_{3}$ and had an average grain size of $0.3 \mu \mathrm{m}$. The $\mathrm{Al}_{2} \mathrm{O}_{3}$ whiskers were obtained by thermal decomposition of aluminum borate whiskers (Shikoku Chemicals Co., $9 \mathrm{Al}_{2} \mathrm{O}_{3} \cdot 2 \mathrm{~B}_{2} \mathrm{O}_{3}$ ) at $1500^{\circ} \mathrm{C}$ for $72 \mathrm{~h}$ in air. ${ }^{5)}$ The scanning electron micrograph of the $\mathrm{Al}_{2} \mathrm{O}_{3}$ whiskers obtained shows in Fig. 1. The whiskers were found to be $\alpha$-phase and good single crystals from X-ray analysis and electron diffraction by TEM. They had approximately $1 \mu \mathrm{m}$ in diameter and 10 to $20 \mu \mathrm{m}$ in length. These starting powders were ball-milled in distilled water for $24 \mathrm{~h}$ and the mixture was dried and then passed through a 16 -mesh sieve (opening size: $1 \mathrm{~mm}$ ). The $\mathrm{Al}_{2} \mathrm{O}_{3}$ whiskers were added to the zirconia powder in the following quantities: 10,20 or $40 \%$ by volume.

Hot-pressing was used as the sintering process. The mixed powders were packed in a graphite mold, pressed to a given pressure, then heated at around $70^{\circ} \mathrm{C} / \mathrm{min}$ to a given temperature, at which it was held for a given time and allowed to cool after the pressure released. The sintering conditions were, temperature $1500^{\circ} \mathrm{C}$, pressure $30 \mathrm{MPa}$ and holding

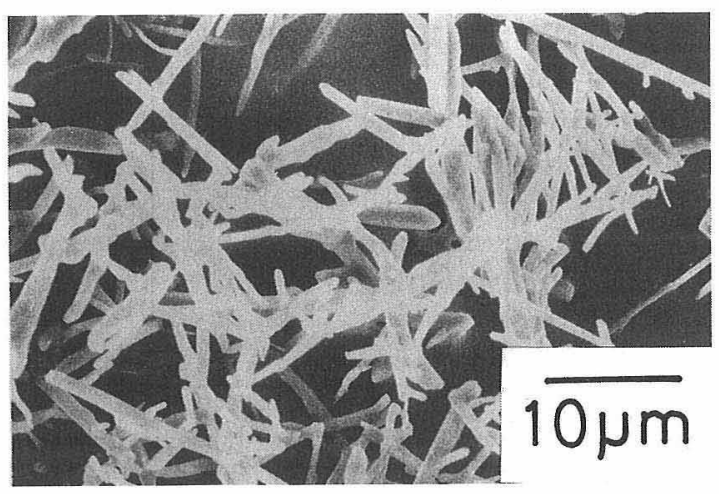

Fig. 1. SEM micrograph of alumina whiskers used in this study. 
time $30 \mathrm{~min}$. The sinter size was approximately $20 \times 40 \times 5 \mathrm{~mm}$.

The sintered sample thus prepared was polished with a \#200 diamond wheel and its bulk density was measured by the Archimedean method.

For the strength test, the tensile face of the sintered sample was polished with a \#800 diamond grind plate into $3 \times 4 \mathrm{~mm}$ square specimen and threepoint bending test was carried out for a $30 \mathrm{~mm}$ span and a loading rate of $0.5 \mathrm{~mm} / \mathrm{min}$. The test for hightemperature strength was performed while each specimen was held at a given temperature for 10 min in air.

Hardness was determined by a Vickers hardness tester at $294 \mathrm{~N}$ for $30 \mathrm{~s}$ and elastic modulus by the bending resonance method (JIS $R$ 1602) on $1 \times 5 \times 40 \mathrm{~mm}$ specimens.

Fracture toughness was determined by the IF and SEPB methods (JIS R 1607), under $294 \mathrm{~N}$ load and $30 \mathrm{~s}$ for the specimens mirror-polished with $1 \mu \mathrm{m}$ diamond paste in the former, and under the three-point bending test with a $30 \mathrm{~mm}$ span and a loading rate of $0.5 \mathrm{~mm} / \mathrm{min}$ for the $4 \times 3 \mathrm{~mm}$ square precracked specimen in the latter.

\section{Results and discussion}

Almost dense composites with relative densities above $99 \%$ were obtained in this sintering condition. $\mathrm{X}$-ray analysis revealed that the zirconia in both the monolithic Z-3Y and the composites consisted of about $10 \mathrm{vol} \%$ monoclinic phase and about $90 \mathrm{vol} \%$ tetragonal phase, similar to the starting zirconia powder, calculated from an equation given by Garvie and Nicholson.6)

Figure 2 shows the effect of $\mathrm{Al}_{2} \mathrm{O}_{3}$ whisker content on the bending strength measured at room temperature. The bending strength increased as whisker content increased from around $940 \mathrm{MPa}$ for the monolithic Z-3Y to around $1180 \mathrm{MPa}$ at whisker content of $40 \mathrm{vol} \%$, which was roughly 1.3 times that of the monolithic Z-3Y. Little difference in the bending strength at whisker content of between $20 \mathrm{vol} \%$ and $40 \mathrm{vol} \%$ is considered to be due to some effect of

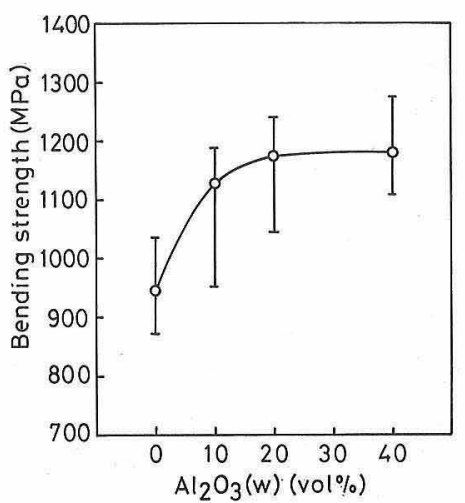

Fig. 2. Effect of whisker content on the bending strength of $Z$ $3 \mathrm{Y}-\mathrm{Al}_{2} \mathrm{O}_{3}$ whisker composite measured at room temperature. thermal mismatch between $\mathrm{Z}-3 \mathrm{Y}$ and $\mathrm{Al}_{2} \mathrm{O}_{3}$. The average thermal mismatch stress in the zirconia matrix was about $150 \mathrm{MPa}$ and $260 \mathrm{MPa}$ at whisker content of $20 \mathrm{vol} \%$ and $40 \mathrm{vol} \%$, respectively, calculated from an equation given by Phillips. ${ }^{7)}$ In the case of $\mathrm{Z}-3 \mathrm{Y} / \mathrm{SiC}$ whisker composite ceramics, the room temperature bending strength decreased with an increase in whisker content because of large thermal mismatch between whiskers and matrices. ${ }^{3), 4)}$ Figure 3 represents the scanning electron micrographs of the fractured faces of the monolithic Z-3Y and the composite with whisker content of $40 \mathrm{vol} \%$. The suppression of matrix grain growth by the incorporation of whiskers has generally some effect on the improvement of the room temperature strength in the whisker reinforced composite ceramics. However, the zirconia grains in this composite were almost same size as those in the monolithic Z-3Y similar to the boron carbide-SiC whisker composite ceramics. ${ }^{8)}$ This implied that the addition of $\mathrm{Al}_{2} \mathrm{O}_{3}$ whiskers had no effect on the growth of zirconia grains, and that the increased strength of the composite resulted from the whiskers bonding strongly to the zirconia grains to bear part of the bending test load.

On the bending tests at $1000^{\circ}$ and $1100^{\circ} \mathrm{C}$, both the monolithic Z-3Y and the composite with 40 vol\% whiskers had almost same strengths (around 300 $\mathrm{MPa}$ ). However, at $1200^{\circ} \mathrm{C}$, the monolithic Z-3Y showed a plastic deformation up to the displacement of $5 \mathrm{~mm}$ and did not fracture but bent, while the composite fractured at the strength of around $300 \mathrm{MPa}$

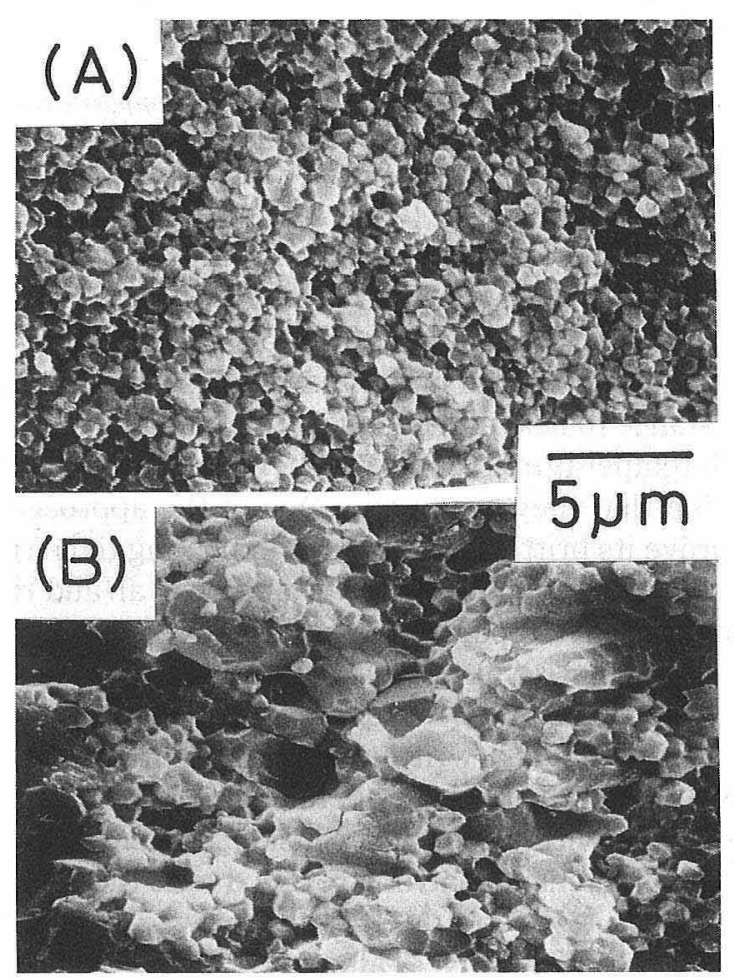

Fig. 3. SEM micrographs of fractured surfaces of Z-3Y, (A), and $\mathrm{Z}-3 \mathrm{Y}-\mathrm{Al}_{2} \mathrm{O}_{3}$ whisker composite with 40 vol\% whiskers, (B). 


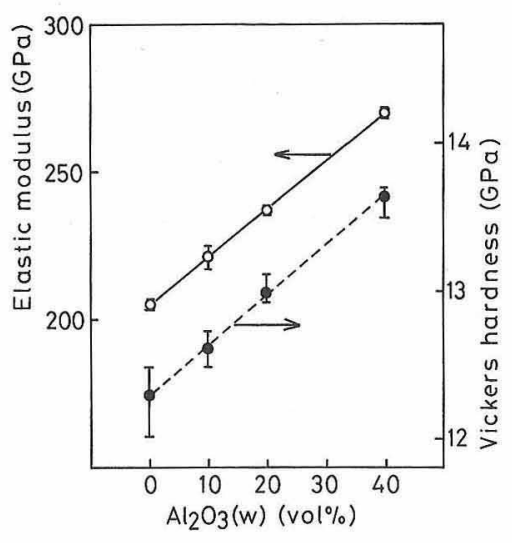

Fig. 4. Effect of whisker content on the elastic modulus and Vickers hardness of $\mathrm{Z}-3 \mathrm{Y}-\mathrm{Al}_{2} \mathrm{O}_{3}$ whisker composite.

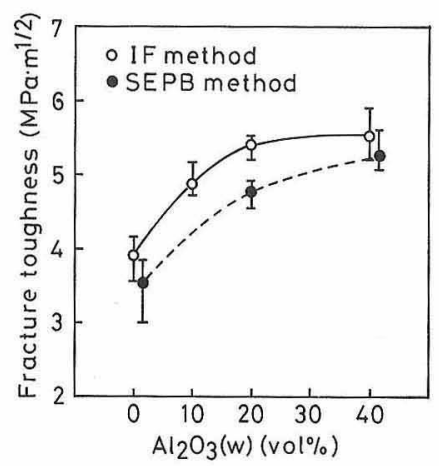

Fig. 5. Effect of whisker content on the fracture toughness of $Z$ $3 \mathrm{Y}-\mathrm{Al}_{2} \mathrm{O}_{3}$ whisker composite.

equivalent to that measured at $1000^{\circ}$ and $1100^{\circ} \mathrm{C}$. Claussen et al. reported that the bending strength of the Z-3Y containing $30 \mathrm{vol} \% \mathrm{SiC}$ whiskers was twice that of the monolithic Z-3Y at $1000^{\circ} \mathrm{C}$, due to the lower thermal mismatch at $1000^{\circ} \mathrm{C}$. ${ }^{3)}$ On the other hand, Kondoh et al. observed that the same composite had lower high temperature strengths than the monolithic Z-3Y, because that cracks occured at the high temperature test. ${ }^{4)}$

Figure 4 shows the effect of $\mathrm{Al}_{2} \mathrm{O}_{3}$ whisker content on the elastic modulus and the Vickers hardness. The elastic modulus increased linearly with increasing whisker content, because that the elastic modulus of $\mathrm{Al}_{2} \mathrm{O}_{3}$ was higher than that of $\mathrm{Z}-3 \mathrm{Y}\left(\mathrm{Al}_{2} \mathrm{O}_{3}\right.$ : $385 \mathrm{GPa}, \mathrm{Z}-3 \mathrm{Y}: 205 \mathrm{GPa}$ ). The hardness showed a dependence on whisker content similar to the elastic modulus. It increased as whisker content increased from $12.3 \mathrm{GPa}$ of the monolithic Z-3Y to $13.6 \mathrm{GPa}$ at whisker content of $40 \mathrm{vol} \%$.

Figure 5 shows the effect of $\mathrm{Al}_{2} \mathrm{O}_{3}$ whisker content on the fracture toughness. The monolithic Z-3Y possessed a fracture toughness of $3.9 \mathrm{MPa} \cdot \mathrm{m}^{1 / 2}$ determined by the IF method and $3.6 \mathrm{MPa} \cdot \mathrm{m}^{1 / 2}$ determined by the SEPB method. Increasing the whisker content increased fracture toughness to $5.5 \mathrm{MPa}$. $\mathrm{m}^{1 / 2}$ by the IF method and $5.2 \mathrm{MPa} \cdot \mathrm{m}^{1 / 2}$ by the SEPB method at a whisker content of $40 \mathrm{vol} \%$.

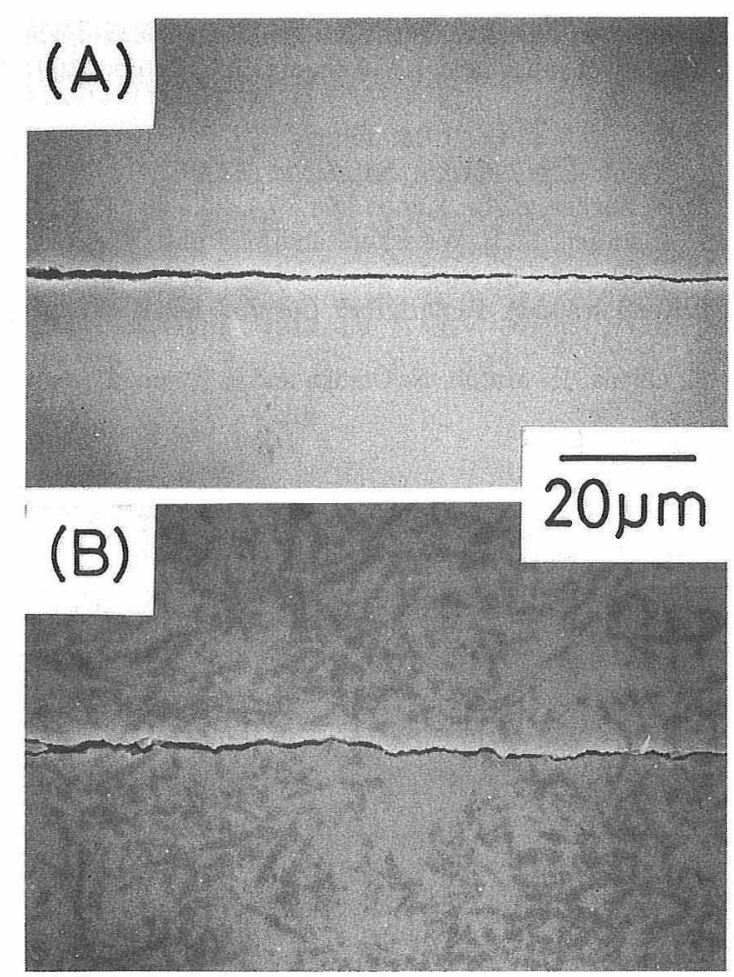

Fig. 6. Crack extension from corner of Vickers indentation in Z$3 \mathrm{Y},(\mathrm{A})$, and $\mathrm{Z}-3 \mathrm{Y}-\mathrm{Al}_{2} \mathrm{O}_{3}$ whisker composite with $40 \mathrm{vol} \%$ whiskers, (B).

Claussen et al. and Kondoh et al. observed that the fracture toughness of a Z-3Y composite with 30 vol\% $\mathrm{SiC}$ whiskers was about 1.7 times as large as that of the monolithic Z-3Y.3),4)

Figure 6 shows the crack extension from the Vickers indents of the monolithic Z-3Y and the composite containing $40 \mathrm{vol} \%$ whiskers. The cracks ran almost straight in the monolithic Z-3Y, while small crack deflection was observed in the composite. Although this composite had a strong interfacial bonding between whiskers and matrices, some pull-out of whiskers occured as seen in Fig. 3. No phase change of zirconia was observed on the fracture surfaces of the composites by X-ray analysis, similar to the results of Claussen et al. and Kondoh et al. ${ }^{3), 4)}$ The increased toughness of the composite, therefore, is considered to result from crack deflection by whiskers and pull-out of whiskers, and possibly some increased elastic modulus shown in Fig. 4.

Some improvement of the strengths and toughness may be achieved by examining still the fabrication conditions of $\mathrm{Al}_{2} \mathrm{O}_{3}$ whiskers and the sintering conditions of this composite or incorporating $\mathrm{Al}_{2} \mathrm{O}_{3}$ whiskers into the zirconia containing $2 \mathrm{~mol} \% \mathrm{Y}_{2} \mathrm{O}_{3}$ having higher strength and fracture toughness than Z-3Y.9)

Acknowledgment The authors greatly thank Dr. Y. Miyamoto of Osaka University for the TEM analysis of $\mathrm{Al}_{2} \mathrm{O}_{3}$ whiskers used in this work and Dr. P. F. Becher of Oak Ridge National Laboratory for his advice and suggestions. 
(This work was presented at the 4th Fall Symposium of The Ceramic Society of Japan held in Yokohama City (October 1991).)

\section{References}

1) N. Tamari, Bull. Ceram. Soc. Japan, 22, 502-07 (1987).

2) P. F. Becher, J. Am. Ceram. Soc., 74, 255-69 (1991).

3) N. Claussen, K. L. Weisskopf and M. Rühle, J. Am. Ceram. Soc., 69, 288-92 (1986).

4) I. Kondoh and N. Tamari, Bull. Gov. Ind. Res. Inst. Osaka, 39, 77-83 (1988).

5) K. Okada, H. Mutoh, N. Otsuka and T. Yano, J. Mater. Sci.
Lett., 10, 588-90 (1991).

6) R. C. Garvie and P. S. Nicholson, J. Am. Ceram. Soc., 55, 303-05 (1972).

7) D. C. Phillips, "Handbook of Composites", Vol. 4, Ed. by A. Kelly and S. T. Milenko, Elsevier (1983) pp. 373-427.

8) N. Tamari, H. Kobayashi, T. Tanaka, I. Kondoh and S. Kose, Seramikkusu Ronbunshi (J. Ceram. Soc. Japan), 98, 1159-63 (1990).

9) K. Tsukuma, Y. Kubota and T. Tsukidate, FC Report, 1, No. 6, 8-14 (1983). 